Article

\title{
Territorial Stigmatisation and Poor Housing at a London 'Sink Estate'
}

\author{
Paul Watt \\ Department of Geography, Birkbeck, University of London, London, WC1E 7HX, UK; E-Mail: p.watt@bbk.ac.uk
}

Submitted: 4 August 2019 | Accepted: 9 December 2019 | Published: 27 February 2020

\begin{abstract}
This article offers a critical assessment of Loic Wacquant's influential advanced marginality framework with reference to research undertaken on a London public/social housing estate. Following Wacquant, it has become the orthodoxy that one of the major vectors of advanced marginality is territorial stigmatisation and that this particularly affects social housing estates, for example via mass media deployment of the 'sink estate' label in the UK. This article is based upon a multi-method case study of the Aylesbury estate in south London-an archetypal stigmatised 'sink estate.' The article brings together three aspects of residents' experiences of the Aylesbury estate: territorial stigmatisation and dissolution of place, both of which Wacquant focuses on, and housing conditions which he neglects. The article acknowledges the deprivation and various social problems the Aylesbury residents have faced. It argues, however, that rather than internalising the extensive and intensive media-fuelled territorial stigmatisation of their 'notorious' estate, as Wacquant's analysis implies, residents have largely disregarded, rejected, or actively resisted the notion that they are living in an 'estate from hell,' while their sense of place belonging has not dissolved. By contrast, poor housing-in the form of heating breakdowns, leaks, infestation, inadequate repairs and maintenance-caused major distress and frustration and was a more important facet of their everyday lives than territorial stigmatisation. The article concludes by arguing that housing should be foregrounded, rather than neglected, in the analysis of the dynamics of urban advanced marginality.
\end{abstract}

\section{Keywords}

advanced marginality; council tenants; dissolution of place; gentrification; housing conditions; neighbourhood; regeneration; sink estate; social housing; territorial stigmatisation

\section{Issue}

This article is part of the issue "New Research on Housing and Territorial Stigma" edited by Margarethe Kusenbach (University of South Florida, USA) and Peer Smets (Vrije Universiteit Amsterdam, the Netherlands).

(C) 2020 by the author; licensee Cogitatio (Lisbon, Portugal). This article is licensed under a Creative Commons Attribution 4.0 International License (CC BY).

\section{Introduction}

This article provides an analysis of territorial stigmatisation, place, and housing conditions at the Aylesbury estate in the London Borough of Southwark and in so doing offers a critique of Loic Wacquant's (2008) influential advanced marginality framework. This south London social housing estate-built by the council (local authority)-is emblematic of the stigmatising 'sink estate' label which has been prominent in UK mass media and political discourse. The Aylesbury estate has also been subject to a long-running controversial regeneration scheme (Southwark Council, 2016), which involves phased demolition and rebuilding "with mixed income new-build housing" (Lees, 2014, p. 924, original empha- sis) the majority of which will probably be private. The article begins with a review of the literature on neighbourhood stigmatisation. It then summarises Wacquant's advanced marginality approach, noting his relative neglect of housing. The research context and methods are outlined. The research findings are firstly discussed in relation to territorial stigmatisation and place, and secondly in relation to poor housing, while the conclusion synthesises the findings.

\section{Stigmatised Neighbourhoods: From 'Slums' to 'Sink Estates'}

Although the 'territorial stigmatisation' concept was coined by Wacquant (2008), its core idea-the stig- 
matisation of certain neighbourhoods along with their populations-has exercised urban sociology at least as far back as the Chicago School (Hastings, 2004). As Damer (1974, pp. 221-222, original emphasis) argues, in addition to any structural disadvantages that the residents of such areas might face, "they can also suffer from the very reputation of the outside world towards them [defined as] a publicly held opinion about a social group or a neighbourhood, which, when negative or pejorative, tends to have a stigmatising effect." Such stigmatised neighbourhoods are variously labelled as 'slums,' 'dreadful enclosures,' 'problem estates,' and more recently 'sink estates' by policy officials and other powerful bodies including the mass media, while their residents are termed as 'rough,' 'problem tenants,' an 'underclass,' and 'anti-social families' (see, among others, Damer, 1974; Gans, 1962; Hastings, 2004; Slater, 2018; Watt, 2008). Such stigmatising labels also form key aspects of the rationale for urban renewal (involving demolition) as has occurred during both the post-war slum clearance period and the contemporary 'new urban renewal' phase which has targeted social housing estates like the Aylesbury (Lees, 2014; Watt \& Smets, 2017).

Two classic urban ethnographies of stigmatised neighbourhoods have highlighted how sociological reality failed to match the lurid 'wine alley' (Damer, 1974) and 'slum' (Gans, 1962) labels. Damer (1974) and Gans (1962) illustrate several enduring themes in research on neighbourhood stigmatisation, themes that are pertinent to the Aylesbury case. First, is that stigmatising labels do not necessarily accord with residents' lived experiences of the neighbourhoods which are far more ordinary, albeit not unproblematic, working-class areas; these are 'places with problems' rather than 'problem places' (Johnston \& Mooney, 2007). Second is that many residents do not accept or internalise the external stigmatising labels. Third, is how neighbourhood stigmatisation is bound up with urban policy discourses and practices, notably in relation to demolition and urban renewal/regeneration.

Damer's 'wine alley' in Glasgow was an inter-war council estate built by the local authority and his study illustrates the long history of public housing stigmatisation in the UK. Certain council estates were characterised by high levels of poverty, crime, and anti-social behavior (vandalism, graffiti, drunkenness, neighbour quarrels, etc.), hence giving rise to the notion of 'problem estates' (Attenburrow, Murphy, \& Simms, 1978), including in Southwark (Coleman, 1990). Such estates were also a 'problem' for housing managers because they were unpopular with tenants who did not want to live there; hence they became 'difficult-to-let' (or 'hard-tolet') resulting in empty properties and above-average turnover rates (Attenburrow et al., 1978; Department of the Environment, 1981). While stigmatisation involved a minority of problem estates during the post-war period, it has widened and deepened in the UK during the last forty years due to neoliberal privatisation policies resulting in the residualisation of social housing (today owned and managed by either councils or housing associations) which has come to be regarded as the 'tenure of last resort' for those too poor to afford homeownership (Hamnett, 2003; Watt, 2008).

During the last 20 years, the dominant British lexicon has shifted away from 'problem estates' towards 'sink estates.' Campkin (2013) has traced the journalistic origins of the 'sink estate' label back to 1976, but argues that it was given oxygen by Tony Blair, the Labour Prime Minister (1997-2007). This occurred in various speeches Blair made, for example in his symbolic postelection 1997 visit to the Aylesbury estate where he mentioned "estates where the biggest employer is the drugs industry, where all that is left of the high hopes of the post-war planners is derelict concrete" (cited in Campkin, 2013, p. 97). As Slater (2018) has shown, the national press usage of 'sink estate' increased exponentially under New Labour (1997-2010; see Johnston \& Mooney, 2007; Watt, 2008). The term 'sink estate' shares many of the same features as the earlier 'problem estate' label, but with a heightened emphasis on crime and antisocial behaviour albeit with an updated stress on drugs and gangs. As Slater (2018) argues, it is the moralistic, behavioural aspects of the 'sink estate' discourse which is prioritised by the national press, rather than material factors such as poverty. A similar moralistic emphasis can be identified in New Labour's urban policy (Watt \& Jacobs, 2000). Estate stigmatisation has taken a further upward turn during the post-crash decade as a consequence of austerity welfare policies (Hancock \& Mooney, 2013; Slater, 2018).

Not only has estate stigmatisation increased, it also forms part of the class-based rationale for regeneration (new urban renewal) involving demolition and rebuilding with extensive private housing for sale or rent: "Symbolic defamation provides the groundwork and ideological justification for a thorough class transformation, usually involving demolition, land clearance, and then the construction of housing and services aimed at a more affluent class of resident" (Kallin \& Slater, 2014, pp. 1353-1354). Such regeneration-related stateled gentrification has occurred at several London social housing estates (Hodkinson, 2019; Watt, 2013) including the Aylesbury as Lees (2014) discusses at length. Similar intertwined processes of social housing residualisation, stigmatisation, and regeneration have been identified in other neoliberal housing policy regime contexts, for example Australia (Jacobs \& Flanagan, 2013; Morris, 2013) and Canada (August, 2014).

\section{Wacquant, Territorial Stigmatisation, and the Dissolution of Place}

The most influential sociological account of contemporary territorial stigmatisation comes from Wacquant in Urban Outcasts (2008). In this book, Wacquant argues that urban areas such as the South Side of Chicago and 
La Courneuve in the Parisian periphery-which prominently include social housing estates or 'projects' in US terms - form epicentres of advanced marginality. These are formed by multiple overlapping strands of sociospatial disadvantage including wage-labour insecurity, disconnection from macroeconomic trends, territorial stigmatisation, the dissolution of place, loss of informal neighbourhood support, and social fragmentation via the creation of a nascent 'precariat.' This article focusses on just two of these issues-territorial stigmatisation and the dissolution of place.

Territorial stigmatisation fuses Goffman's notion of stigma as 'spoiled identity' together with Bourdieu's account of symbolic violence (Flint \& Powell, 2019): "Advanced marginality tends to be concentrated in isolated and bounded territories increasingly perceived by both outsiders and insiders as social purgatories, leprous badlands at the heart of the postindustrial metropolis where only the refuse of society would agree to dwell" (Wacquant, 2008, p. 237). Wacquant (2008, p. 238) spatialises Goffman's approach by suggesting that a "taint of place" (or 'blemish of place') is superimposed onto social stigmata such as poverty, ethnicity, or migrant status, but importantly this taint negatively affects residents irrespective of "whether or not these areas are in fact dilapidated and dangerous" (Wacquant, 2008, p. 239). Such effects include spatial discrimination (for jobs), but also residents' internalisation of spatial stigma by hiding their address, wanting to leave the area, see it demolished, etc. In fact, Wacquant (2008, p. 169) claims that territorial stigmatisation is "arguably the single most protrusive feature of the lived experience of those entrapped in these sulfurous zones." Furthermore, regarding place belonging and attachment:

The obverse side of this process of territorial stigmatization is the dissolution of 'place': that is, the loss of a humanized, culturally familiar and socially filtered locale with which marginalized urban populations identify and in which they feel 'at home' and in relative security. (Wacquant, 2008, p. 241)

In other words, residents' place belonging and neighbourhood-based sense of community have atrophied under the combined weight of the vectors of advanced marginality which are especially pronounced in the US hyper-ghetto but which also occur in less extreme form in the social housing estates of the Parisian banlieues.

The concept of territorial stigmatisation has proved influential in understanding how advanced marginality is constructed in relation to social housing estates including in the UK (Hancock \& Mooney, 2013; Kallin \& Slater, 2014). This article does not attempt to review Wacquant's work in its entirety (Flint \& Powell, 2019), but instead makes three critical contributions.

First, the article builds upon existing studies of social housing estates which have revealed less resident in- ternalisation of territorial stigmatisation than Wacquant suggests and more positive place attachment and sense of belonging than his 'dissolution of place' implies (August, 2014; Garbin \& Millington, 2012; Jensen \& Christensen, 2012; Morris, 2013).

Second, the article addresses how the advanced marginality framework has tended to neglect housing, as Powell and Robinson (2019) argue, a neglect which Wacquant (2019) acknowledges. To some extent, Wacquant is being unfair to himself since Urban Outcasts includes several comments on housing, for example on the dilapidated state of buildings which reinforces marginality (Wacquant, 2008, pp. 82, 158-160, 220). Nevertheless, housing is distinctly marginal-rather than central-within Wacquant's advanced marginality conceptualisation. In addition, there is a tendency within some UK literature on advanced marginality to stress the symbolic and representational aspects of social housing estates as seen in the emphasis placed on the mass media and right-wing think-tanks in producing territorial stigmatisation (Hancock \& Mooney, 2013; Slater, 2018). By contrast, the material fabric of such estates-housing and the built environment-is less well scrutinised (although see Baxter, 2017).

Third, despite Wacquant's rhetorical flourish-that territorial stigmatisation is, arguably, the most significant aspect of residents' lived experiences-there is little understanding of the relative importance of stigmatisation in residents' everyday lives and especially relative to housing. For example, although Kelaher, Warr, Feldman, and Tacticos (2010, p. 383) suggest that territorial stigmatisation has independent negative health effects on residents, they don't scrutinise how only $5 \%$ of interviewees' neighbourhood dislikes involved "negative reputation" well below the $18 \%$ for physical environment. In a paper on the Regent Park estate in Toronto, Canada, August (2014) examines territorial stigmatisation alongside housing neglect and crime. However, although August acknowledges that stigmatisation is not the sole problem tenants face, she does not adjudicate how significant it might be relative to other factors. Therefore, one of the main purposes of this article is to begin to assess the relative significance of territorial stigmatisation from the perspective of the everyday lives of the residents of a stigmatised 'sink estate,' rather than to simply assume that it is of central significance as Wacquant's advanced marginality framework implies.

\section{Context and Methods}

This article is based on a multi-method case study of the Aylesbury estate which forms part of a much larger research project on public/social housing and estate regeneration in London (Watt, in press). The latter's research focus is how estate residents experience regeneration with reference to housing, place attachment/belonging (to homes and neighbourhoods), and inequality. It examines several London estates at various stages of the re- 
generation life-cycle. Although reference is made to the overall project, the focus here is the Aylesbury because it is probably the London estate which has been the most stigmatised, not least due to the (in)famous role it played in New Labour's urban policy.

The Aylesbury estate is located in the London Borough of Southwark, south of the Elephant and Castle town centre and the smaller, now-demolished Heygate estate. It was built by Southwark Council from 1963-1977, and is (or was) one of the largest estates in Europe with approximately 7,500 people living in 2,759 dwellings spread over 28.5 hectares (Southwark Council, 2005). The dwellings are arranged in 4-14 storey blocks and the estate is an archetypal example of postwar 'Brutalist' modernist municipal architecture, even though it also has extensive green space (Figure 1). Like most London estates, the Aylesbury is largely working class but it has become demographically more multiethnic and less white British; by 2001, 61\% of its residents were from black, Asian and minority ethnic (BAME) groups compared to just $8 \%$ in the UK (Blandy, Green, \& McCoulough, 2004, p. 15). Ninety percent of households were social renting (mainly council tenants) compared to $20 \%$ in England (Blandy et al., 2004). By 2005, around $12 \%$ of Aylesbury properties had been sold to sitting tenants under the 'Right-to-Buy' (RTB) scheme (Southwark Council, 2005), which was a key plank of Thatcherite neoliberal housing policy (Hodkinson, 2019).

During the late 1990s, the Aylesbury estate was the subject of various regeneration area-based initiatives, including the Single Regeneration Budget and Sure Start, but most significant was the New Deal for Communities (NDC) which was an ambitious $f 56 \mathrm{M}$, ten-year regeneration programme launched in 1998 (Centre for Regional Economic and Social Research [CRESR], 2015). Of the 39 England NDC Partnerships, ten were located in London and several of these focussed on large council estates like the Aylesbury (Watt, 2009). The NDC areas were targeted because they were spatial concentrations of social exclusion including high levels of poverty, deprivation, and crime (CRESR, 2015; Watt, 2009). The NDC areas, but especially the London estates, were also extremely physically rundown having experienced many years of underinvestment in the physical dwellings and estate environment (Bennington, Fordham, \& Robinson, 2004; Watt, 2009 , in press). In 2005, Southwark Council decided that it lacked sufficient funds to refurbish the Aylesbury estate and embarked upon comprehensive redevelopment involving phased demolition and rebuilding but with a substantial amount of new private housing; Notting Hill Housing Trust was subsequently chosen as the development partner (Southwark Council, 2005, 2016).

The research findings are drawn from several primary and secondary data sources. Fieldwork/participant observation was undertaken by the author via attendance at the following Southwark events which included Aylesbury residents' participation (2009-2018): eighteen housing, regeneration, and community meetings; Compulsory Purchase Order (CPO) inquiries (three days in 2015 and one in 2018); and several demonstrations. In-depth interviews were conducted during 2014-2017 with five long-term residents-two secure council ten-

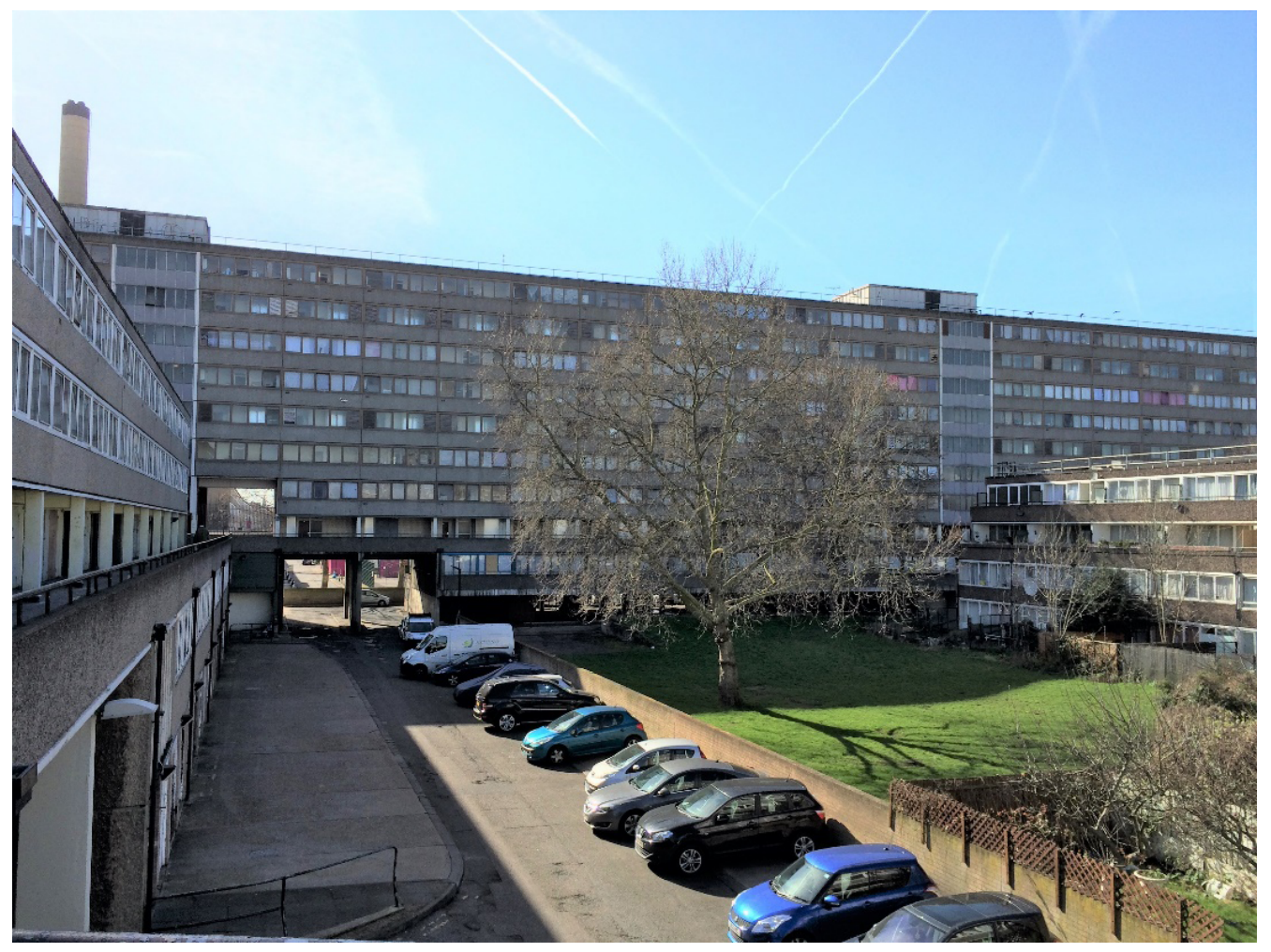

Figure 1. Aylesbury estate, 2017. Source: Paul Watt. 
ants and three leaseholders who had bought their flats under the RTB-plus two charity workers based at the estate. Shorter interviews were conducted in 2015 with three council tenants and three temporary tenants; the council placed the latter in empty properties on a temporary non-secure basis while the estate was undergoing regeneration (see Watt, 2018a). Extensive newspaper analysis was undertaken including web-based sources (local and national press) and archival research on two local newspapers, Southwark News and the South London Press. Because the Aylesbury estate was the subject of an NDC, numerous research and consultancy reports are available, but which have not thus far received focused academic assessment (Beatty, Grimsley, Lawless, Manning, \& Wilson, 2005; Blandy et al., 2004; Castle \& Atkinson, 2004; Christmann, Rogerson, \& Walters, 2003; CRESR, 2015; ERS, 2010; Opinion Research Services [ORS], 2009). Two post-NDC reports are also referred toone on BAME unemployment (Murray, 2012) and one on residents' attitudes in 2014-2015 (Social Life, 2017). These various reports are based on resident surveys, interviews, and official statistics.

The Aylesbury estate has been the subject of considerable academic scrutiny including excellent accounts of the mass media's contribution to the development of its 'sink estate' label and how this was reflected in the official demolition rationale (Campkin, 2013; Lees, 2014; Romyn, 2019). Various studies have also argued that the Aylesbury's reputation is exaggerated and does not accord with residents' lived experiences (Baxter, 2017; Lees, 2014; Rendell, 2017; Romyn, 2019), a view this article concurs with. However, despite their rich findings, the existing publications do not adequately calibrate how the estate-and residents' experiences and opinions of itchanged over time from the 1990s onwards. By employing secondary analysis of the quantitative data drawn from the above reports, this article provides a more nuanced and calibrated account of such changes. The combination of this quantitative analysis with qualitative and newspaper data therefore facilitates a more rounded, temporally specific, and spatially contextualised analysis of the Aylesbury estate vis-à-vis territorial stigmatisation, place, and housing conditions than hitherto available.

\section{Territorial Stigmatisation and Place at the Aylesbury Estate}

The building of the Aylesbury estate involved cost-cutting measures which negatively impacted it from the very beginning, while it also suffered from various early problems, including vandalism, which led to its classification as 'hard-to-let' (Boughton, 2018; Carter, 2008). As Romyn (2019) illustrates, the Aylesbury estate was subject to negative local press reports during the 1970s and 1980s. However, it gained a high-profile national media presence from the 1990s onwards-for example being part of "No-Go Britain" ("No-go Britain: Where, what, why," 1994)-a profile which effectively fused it with the 'sink estate' label (Campkin, 2013). Since 1997, the Aylesbury's reputation as a 'tainted place' in Wacquant's terms has become firmly embedded in national mass media and policy discourse. This was achieved via repetitive newspaper phrases including the 'notorious estate' trope: "Britain's most notorious housing estate" (The Independent, 19 October 2008, cited in Romyn, 2019, p. 141). As Campkin (2013, p. 96) argues, such stories "have repeatedly naturalised the interpretation of the Aylesbury as a crime-ridden dystopia," a reputation which has also formed part of the demolition rationale (Lees, 2014).

\subsection{What Kind of 'Tainted Place'?}

The 1998 Aylesbury NDC delivery plan painted a grim picture of extensive deprivation in terms of poverty, unemployment, crime, ill health, and low education (ERS, 2010), all of which amounted to "staggering" figures and the estate being portrayed as "a study in social exclusion" (Helm, 2000). As well as most residents being social renters, $24.6 \%$ of Aylesbury NDC households were on low incomes, nearly double the $13.3 \%$ England average (Blandy et al., 2004, p. 15). Unemployment in the Faraday ward (where the Aylesbury estate is located) stood at $8.2 \%$ in 2001 well above the England and Wales' average of $3.4 \%$ (Castle \& Atkinson, 2004, p. 54). Not only was the Aylesbury area deprived, residents' subjective experiences also appear to suggest that a dissolution of place, in Wacquant's terms, might be underway. Fear of crime, for example, was the highest among all the NDC areas and 2.5 times greater than the NDC as a whole (Beatty et al., 2005; Christmann et al., 2003), while neighbourhood satisfaction was $49 \%$ in 2000 compared to a national 85\% (ERS, 2010, p. 33).

Despite the above 'staggering figures,' a close reading of the NDC reports, allied to the local newspaper analysis, suggests a much more nuanced reality, especially when one takes the Aylesbury's south-east London location into account, an inner-city area long-associated with poverty and crime (Robson, 2000). Among the 39 NDC areas, the Aylesbury NDC was actually the 6th least deprived using the 2004 Index of Multiple Deprivation (CRESR, 2015, p. 12). As such, it appeared in the 10-20\% most deprived areas in England at 4,633rd out of 32,482; in other words, there were 4,632 more deprived areas in England than the Aylesbury estate. Furthermore, the Aylesbury NDC had the lowest level of residents reporting "health not good" in 2002 at $14 \%$ compared to the $23 \%$ NDC average (CRESR, 2015, p. 15). Thus, there were far more deprived NDC areas than the Aylesbury, even if they received nothing like the same national media attention as this 'notorious,' 'sink estate.' In addition, while Aylesbury residents were deprived by national measures, their disadvantages were not 'staggering' by Southwark's own standards-as the ninth most deprived local authority area in England in 2000 (Castle \& Atkinson, 2004). In 2000, Faraday was only the thirteenth most deprived 
ward in Southwark, while the $8.2 \%$ Faraday unemployment rate was not greatly above the $6.2 \%$ borough average (Castle \& Atkinson, 2004).

Despite extensive fear of crime, the Aylesbury NDC area had lower levels of victimisation in comparison to other NDC areas but also in comparison with Southwark as a whole (Beatty et al., 2005). When comparing crime rates for violence, burglary, theft, and criminal damage in each NDC area in 2002-2003 with the relevant local authority, the Aylesbury NDC "consistently reveals crime rates which are about half that for the parent local authority [Southwark]" (Beatty et al., 2005, p. 36). Furthermore, within the context of the routine plethora of crime-related stories in Southwark News and the South London Press, the Aylesbury does not emerge as an outlier. If anything, the Aylesbury featured less prominently relative to other far less 'notorious' south London estates-for example, "tenants set to hire security guards in fight against crack house plague" (Quinn, 2002), referring to another Southwark estatesuggesting that the Aylesbury's crime and anti-social behaviour problems were not in fact extraordinary once located within their inner-city London context.

If the above indicates that the Aylesbury's 'sink estate' reputation was exaggerated at the start of the NDC, later reports highlight notable improvements which are, at least in part, due to NDC and other regenerationrelated community development initiatives (ERS, 2010; Social Life, 2017). While poverty and unemployment, especially BAME unemployment, remain problematic issues at the Aylesbury (Murray, 2012; Social Life, 2017), the estate's deprivation ranking improved "largely driven by reductions in crime and improvements in educational attainment" (ERS, 2010, p. 31). Fear of crime also reduced-from around $70 \%$ of residents saying they felt afraid to walk in the area alone after dark in 2002 (Castle \& Atkinson, 2004, p. 51), 65\% felt safe to do so by 2015 (Social Life, 2017, p. 19). Thus, "there was a strong consensus among residents and agencies that the Aylesbury Estate is no longer a dangerous place, and that crime is far lower on the estate than the public tend to believe" (Social Life, 2017, p. 31), even though some Aylesbury residents continue to be concerned about antisocial behaviour in the estate's public spaces (Baxter, 2017). Neighbourhood satisfaction markedly improved from $49 \%$ in 2000 to $63 \%$ in 2008 (ERS, 2010) and then to $89 \%$ in 2015 (Social Life, 2017, p. 19), although the latter was somewhat higher in the new housing association blocks than the pre-existing council estate. The Social Life $(2017$, p. 31$)$ report concluded that "generally residents were happy with the area as a place to live," while $89 \%$ said that they belonged to the neighbourhood, $25 \%$ above the UK level (Social Life, 2017, p. 19); this indicates that residents' sense of place has not in fact dissolved. Such survey findings are borne out by my interviews and fieldwork which suggest broadly positive neighbourhood place belonging (at least until the blocks were being emptied out due to demolition), alongside scepticism regarding the estate's 'notorious' reputation. Salma (council tenant, black) had lived at the Aylesbury since the late 1990s. She worked locally as a part-time carer and described her everyday routine including her appreciation of the estate's location and transport connections (cf. Social Life, 2017):

I have never seen anything bad in this area. I can go to the mosque and I feel safe in the Old Kent Road. At Ramadan you have to pray in the night-time, I walk there, I don't have a car. I've always felt safe, I go shopping-if you want to go anywhere in London, you can get anywhere by bus, there are lots of different buses. I don't know why they say the Aylesbury estate is so bad with crime.

Dolores (leaseholder, Asian) loved the area because of its proximity to the West End. During the many years she had lived at the estate, Dolores had never been burgled and had not even heard of any break-ins. Once her bag had been stolen, but "this is the only thing what has happened to me since last twenty years, but after that it's safe, I feel safe to come here and sometimes I come at 1 o'clock [in the morning] and it's not a big deal."

Although many residents had repairs and maintenance problems with their flats and blocks-as discussed afterwards-there was at the same time an appreciation of the intrinsic qualities of their flats which led to a sense of home, as Baxter (2017) has highlighted. The flats' generous size and views (for those on the higher floors; Figure 2) were prominent features of such domestic place attachment: "I like the views and this is a lovely massive 1-bed flat" (Julie, temporary tenant, white British). Dolores loved her "very spacious flat" which she had bought under the RTB. Like many working-class RTB homeowners on London's estates, this purchase reflected Dolores' desire not to leave her home or area, but instead to fix herself in place (Watt, in press): "This is home and when I come in the night and then you see the lights and it's just nice."

\subsection{Residents' Responses to Stigmatisation}

The above indicates how the Aylesbury was "less a 'problem estate' than an estate with problems" (Boughton, 2018, p. 223). However, even if sociological reality was not in accordance with the estate's external 'taint of place,' Wacquant (2008) argues that territorial stigmatisation does its work irrespectively notably via resident internalisation, specific dimensions of which are discussed in the next paragraphs. While some resident internalisation has occurred, there is also substantial evidence of Aylesbury residents either disregarding, rejecting, or resisting territorial stigmatisation (see Lees, 2014, especially on resistance).

In terms of disregard, when a group of unemployed BAME estate residents were asked about barriers to employment, they mentioned racial discrimination/ethnic 


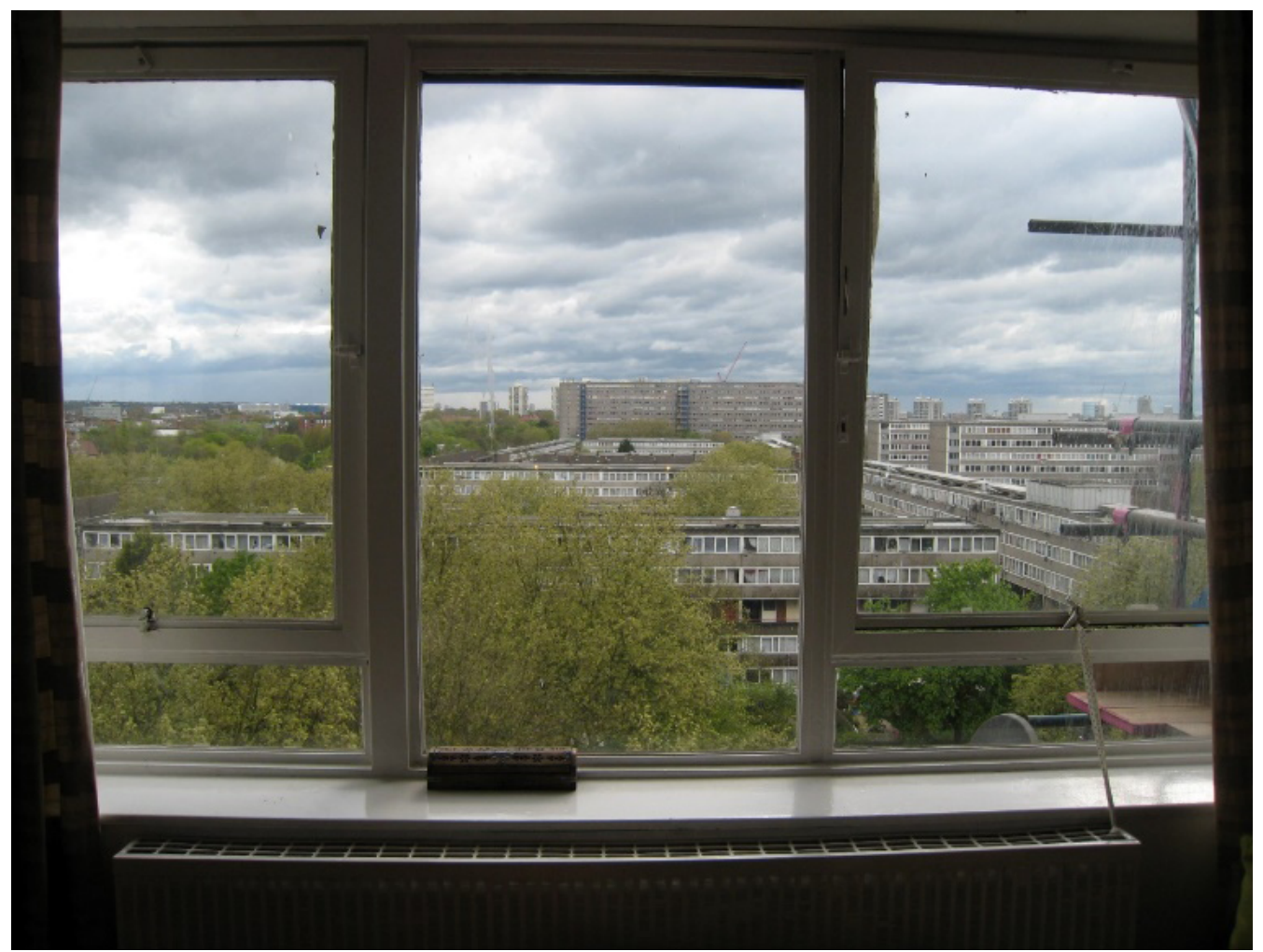

Figure 2. Aylesbury estate: Tenant's treasured view, 2012. Source: Paul Watt.

stereotyping, language and having a criminal record, but not territorial stigmatisation (Murray, 2012). As above, Aylesbury residents have also rejected the estate's reputational blemish while expressing considerable belonging to their homes and neighbourhood. Following Tony Blair's visit to the estate, two locally-engaged women wrote a letter to the local newspaper highlighting their objection to the negative media attention his visit had unleashed: "The Aylesbury Estate is not the 'Estate from Hell' which has been much publicised in the media; it simply needs a kick start from the Government to get more money to enhance the community" (Harrison \& Lauder, 1997). At a 2010 housing meeting, an elderly female Aylesbury resident stood up and passionately denounced the disjunction between the estate's reputation and her active home-making: "I've worked hard on my flat, we've been working on our homes, but we're told by PR campaigns that this is the estate from hell." Among the interviewees, Gesil and William, a married black couple living in a leasehold flat, did have a negative view of the estate when they arrived during the mid-1990s while their friends warned them about its reputation-indicative of internalised stigmatisation: "When we first moved in here, nobody wants to come here, nobody" (Gesil). However, they thought the Aylesbury had become safer over the years due to the crime-control measures, while they had also "made a community" - "we feel like a small family there, that's how it felt...with the neighbours" (Gesil) - that is before their block had emptied out due to the 'decanting' of tenants. There is also evidence of collective active resistance to the estate's taint of place, for example via the work of the Aylesbury Tenants and Leaseholders First campaign, as Lees (2014) and Romyn (2019) discuss, including effectively challenging Channel 4 television's stereotypical ident (logo; Beanland, 2014).

Wacquant (2008) suggests that the internalisation of territorial stigmatisation incorporates residents' hiding their address, wanting to leave the neighbourhood and preferring it to be demolished; each will be examined in turn. A newspaper article indicated some resident internalisation, for example by not inviting friends to visit (Barton, 2005). The Social Life (2017, p. 31) report also noted how "the negative portrayal of the estate in the past-in different films, TV series, and in the Channel 4 ident-is resented by residents, and some have internalised this, leading to feelings of shame." As one longterm resident said, "I've been embarrassed to say it's where I live" due to the Channel 4 ident (Beanland, 2014). As a way of countering such stigmatisation, a Notting Hill Housing Trust spokesperson suggested that the redeveloped estate could be rebranded to "something like 'Walworth Village' or 'Walworth Quarter"' (Morgan, 2014). The chairperson of the Aylesbury Tenants and Residents Association agreed with this rebranding: "If something goes wrong in this area, everyone thinks it's the Aylesbury. I don't want [the name Aylesbury] and most other residents don't want it either" (Morgan, 2014). Such blanket condemnation does not, however, accord with resident survey evidence since "nearly 70 percent said that they would tell others that they live on the Aylesbury Estate, suggesting that the stigma is not as great as some suggest" (Social Life, 2017, p. 31). 
We have already seen how neighbourhood satisfaction at the Aylesbury increased since 2000, but did residents want to leave their homes and the estate? In 2008, 37\% of Aylesbury survey respondents wanted to move from their current property, greater than the $30.6 \%$ Southwark average (ORS, 2009, p. 18) which might be considered indicative of territorial stigmatisation. However, when asked why they would like to move, the main reasons at the Aylesbury were housing-related (for example, wanting a bigger or better home), with area factors (for example, disliking the area or crime concerns) of secondary importance (ORS, 2009). A later Aylesbury estate survey found that $90 \%$ of respondents planned to remain as residents "for a number of years" $22 \%$ higher than the UK average (Social Life, 2017, p. 19). During field work and interviews, I came across no residents who wanted to leave because of territorial stigmatisation and the estate's taint of place. Instead, there was considerable intention to stay put despite potential demolition: "I like to stay in my area and not move from the Aylesbury estate. I want to stay in my flat, I don't want to move. I like my garden; I grow tomatoes, green chillies, and coriander there" (Salma). Like Dolores, Gesil and William had bought their flat under the RTB because they wanted to remain in the area: "We did not buy this to move out, we want to stay here-the children love the place." Such place belonging not only challenges the Aylesbury's 'notorious' reputation-as the 'estate from hell' - but is also sharply distinct from the Chicago hyper-ghetto where "the only route they [residents] see for improvement is to move out, to which nearly all aspire" (Wacquant, 2008, p. 178).

Perhaps the Aylesbury residents had so incorporated territorial stigmatisation that they enthusiastically embraced the bulldozing of their homes and estate? The initial NDC redevelopment proposed a stock transfer to a housing association, involving extensive demolition and sale of land to private developers. A minority of residents accepted this vision of regeneration, but it also proved controversial since others argued that it amounted to privatisation and gentrification (Lees, 2014). Despite widespread recognition that the estate needed extensive refurbishment, there was a $73 \%$ 'no vote' against transfer based on a $72 \%$ turnout in late 2001 (Mullany, 2002a). Not only did this high turnout quash notions that the estate was an enclave of social disengagement and apathy-hence challenging the notion of an entrenched 'dissolution of place' - the result also indicates extensive scepticism regarding the regeneration-as-demolition proposal. Dolores explained why she had voted against stock transfer: "Because I love my home, my place, and because I think it was going to be more difficult to get another council flat somewhere else." Subsequent consultation exercises found a small majority (53\%) of households in favour of demolition/redevelopment, but based on a $45 \%$ sample of households (Southwark Council, 2005, p. 11) as compared to the $72 \%$ ballot turnout. It is unclear, however, what kind of 'promises' were made regarding rehousing which might well have contributed towards this apparent shift from the earlier ballot result. Some residents favoured demolition, but this was more due to wanting to escape from poor housing conditions rather than avoiding stigmatisation. Hurmine (council tenant, black) had lived at the estate for over ten years and thought it should be demolished because "the council won't do anything for people because it's infested and old, I've got mice here, it's very infested."

Like the 2016 UK vote in favour of Brexit, the council's 2005 demolition decision has proved highly controversial and substantial numbers of Aylesbury residents have consistently argued for refurbishment instead-43\% in one consultation (ERS, 2010, p. 18) and $90 \%$ in another (Southwark Council, 2016, p. 31). A determined group of Aylesbury residents have also mounted a sustained campaign against demolition based on wanting to preserve their existing homes and community, a campaign that dates back to the 2001 anti-stock transfer vote (Watt, 2018b). Part of this campaign has involved actively resisting the Aylesbury's tainted reputation, as seen in this letter by five residents and one Southwark supporter:

Our Aylesbury Estate is not crime-ridden or about to fall down. We don't want to move from our soughtafter spacious, solid, secure tenanted flats which are of a higher standard of sound insulation and open space than a lot of other council housing-and generally miles better than recent (higher rented) housing association ventures. The problem is that the Government, Aylesbury NDC and Southwark council deliberately paint a grim, desperate picture of the Aylesbury, and choose to fail to do basic maintenance of lifts, heating and rubbish chutes. (Briden, Corbyn, Dennis, Esteve, Hibbert, \& Tarrawally, 2005)

This letter encapsulates a common fieldwork finding, as discussed further below-that residents thought that the council was effectively running the estate down via inadequate maintenance of the buildings. In addition, Aylesbury leaseholders mounted legal CPO challenges to demolition in 2015 and 2018; part of their case involved wanting to remain in their existing area, not least because it is a welcoming multi-ethnic neighbourhood (Hubbard \& Lees, 2018; Rendell, 2017; Southwark Council, 2016). The equation of demolition with the interrelated class and ethnic transformation of the areaassociated with state-led gentrification-was a prominent complaint in fieldwork and interviews. Gesil and William were explicit that they were de facto the 'wrong sort of people'-too working-class and too black-for the gentrification (or 'social cleansing' as they called it) that was occurring via demolition. Alongside other leaseholders who contested demolition, this couple knew that they would be unable to afford one of the new private properties or even the so-called 'affordable housing' (Hubbard \& Lees, 2018; Southwark Council, 2016). 
Hence, they faced the prospect of being forced out of the area, something that they bitterly resented after having lived through the estate's earlier 'bad times': "Now that the place is coming up, they [council] want us to move out" (Gesil). Aylesbury residents were only too well-aware of the fate of the nearby Heygate estate leaseholders, most of whom were displaced away from the immediate area while many had to leave London altogether (Flynn, 2016).

In conclusion, for such a tainted place, there is a remarkable degree of resident disregard, rejection, and active resistance of territorial stigmatisation at the Aylesbury estate rather than the widespread and deeplyfelt internalisation that Wacquant (2008) has identified in his US and French advanced marginality exemplars. Having said that, interviewees described how the Aylesbury's reputation negatively affected their lives in one very practical way-London black-cab taxi drivers were reluctant to either pick them up or drop them off at the estate: "Usually I come by bus and then I go to Elephant and Castle, and I babysit there and then I take a mini-cab from there to here, but the black cabs they don't like to come here" (Dolores). William thought racism might be a factor as connected to the estate's large BAME population-"Black cabs are mainly white people." Although this expression of stigmatisation was inconvenient and annoying, it was also something that those affected had learned to cope with by using alternative means of transport (for example mini-cabs). By contrast, it was much more difficult for residents to cope with their poor housing conditions as I now discuss.

\section{Poor Housing}

Poor housing conditions at the Aylesbury are of longstanding nature and reflect long-term, widespread under-investment in social housing that has badly affected London council estates (Bennington et al., 2004; Boughton, 2018; Watt, 2009, 2013, in press). Council housing in Southwark was under-invested in for decades and even though Southwark was a major beneficiary of New Labour's nationwide, Decent Homes programmewhich began in 2001 and aimed to improve social housing properties-"funding was insufficient to deal with the scale of the problem" in the borough (Luba, 2012, p. 24). It wasn't until 2011 that Southwark Council embarked on a pro-active and co-ordinated borough-wide housing investment programme (Luba, 2012).

Despite appreciation of their spacious and fundamentally sound homes, Aylesbury residents had many concerns regarding landlord repairs and maintenance as well as the estate's overall physical condition (Baxter, 2017; Lees, 2014; ORS, 2009; Social Life, 2017). What is striking is that by contrast with the improvements in neighbourhood satisfaction, crime, and fear of crime, there was no equivalent improvement in the state of housing and physical infrastructure over the NDC period. In fact, the 2001 stock transfer resulted in dimin- ished upkeep: "With the council waiting to see if most of the estate would be demolished, major repairs were put on hold" (Mullany, 2002b). A post-ballot survey indicated residents' future priorities included "improvement to homes, such as double glazing, and work to kitchens and bathrooms, with health and community facilities, a youth centre and employment and training provision needed on the estate" (Mullany, 2002b). However, while the community development parts of the NDC went ahead following the vote against transfer, the housing aspects stalled. In fact, "The delay in pursuing substantial physical regeneration of community or housing facilities earlier within the programme" was identified as a key failure of the Aylesbury NDC (ERS, 2010, p. 5). In addition, several London regeneration estates were also either partially or fully removed from the Decent Homes programme because they were due for demolition (Watt, 2013, in press); the Aylesbury itself received no Decent Homes funding until 2015-2016 (Southwark Council, 2019).

Such delays and general under-investment meant that $45 \%$ of Aylesbury residents had at least one serious problem with their property by 2008 , notably "damp penetration or condensation and heating or plumbing" (ORS, 2009, p. 14). This housing report went onto show that $57.5 \%$ of Aylesbury households were living in unsuitable housing, $28.0 \%$ had major disrepair, and $22.1 \%$ were overcrowded; the respective Southwark figures are $31.1 \%, 9.6 \%$, and $11.3 \%$ indicating much worse quality housing at the Aylesbury compared to the borough average (ORS, 2009, p. 23). Indeed, $44 \%$ of Aylesbury council rented properties were classified as non-decent in 2010 compared to 31\% across Southwark in 2011 (Luba, 2012, pp. 27-28).

Not only was poor housing extensive at the Aylesbury, but interviews and fieldwork indicate the depths of distress and frustration that the remaining residents experienced. Mohammed (council tenant, South Asian) described his family's housing problems: "There's no hot water, its freezing sometimes. There's a lot of repairs' issues, there's rats and the heating's messing up. A couple of days ago we had no hot water. I live with my gran [grandmother], she shouldn't have to boil water." Salma had a leak in her flat at one point and spent four days without any electricity because it had been turned off; eventually she and her daughter were moved to a hostel for several months while the work was undertaken. Poor housing included damp, leaks, inadequate heating and hot water supply, electrical hazards, infestation, and poor quality/non-existent repairs, as well as overcrowding. It is these conditions that are generally uppermost in London social housing estate residents' everyday problems and priorities (Watt, in press), while they also have a detrimental impact on health and well-being (Ministry of Housing, Communities and Local Government, 2018; Wilson, O’Donnell, Bellis, \& Barton, 2019).

Aylesbury residents felt that they were living in a poor physical environment, but also one which was if 
anything deteriorating due to worsening housing services. A 2015 meeting involved a group discussion with twelve tenants and leaseholders regarding the regeneration. They despairingly emphasised the worsening physical environment, mainly regarding their own homes but also the estate in general. A male long-term council tenant said:

My flat is in a massive state of disrepair due to many months of no heating and leaks from the neighbour upstairs. There's big holes in the floor, leaks and mould, but I don't want them [council] to do a bodge job as they've done in the past.

A female resident described how she had "water pouring down the wall due to private tenants next door." A young man with two small children reported water coming through the ceiling, but "the council said it's not an emergency and that I had to wait until Monday, the weekend [repairs] team cannot do it." An older woman described how when her sink unit collapsed, the worker who came to her flat had been told by his supervisor just to "look at it, but he felt sorry for me and he did fix it." Among the interviewees, Carol (council tenant, black) had no immediate repairs' issues, but described how the council had refused to mend her broken kitchen cupboards: "They said it's not their job, so I had to go B\&Q and fix it privately because I got so fed up."

One recurrent complaint regarded the malfunctioning collective heating and hot water system:
Three mums from the Aylesbury Estate's Calverton block have been contacting the News since December [2016] to vent their frustration about the ongoing problems. (News Desk, 2017)

Residents of condemned flats have been left freezing in the snowy conditions after a temporary boiler fix failed to hold....Many say the boilers have been a continuing problem for months. (Porter, 2018)

Residents lobbied the council about this issue; one complaint contained 200 signatories (Southwark Council, 2018). The relevant Councillor admitted that "there have been issues on the estate, mostly with boiler and associated plant" (Southwark Council, 2018, p. 2). According to Johnston (2019), the council paid $£ 334,666$ in compensation to Southwark council tenants due to heating and hot water problems and the bulk of this - around $£ 319,000-$ was paid out to the residents of just two larger estatesAylesbury and Wyndham.

In the light of such persistent housing problems, it is hardly surprising that Aylesbury residents cynically felt the council was neglecting the estate due to its imminent demolition. Similar views had also been expressed at the nearby Heygate-"As an estate that has been earmarked for possible demolition and rehousing, many residents feel that equipment has been patched up rather than replaced, causing problems that repeatedly flare up in the cold weather" (Eighteen, 2002). A flourishing 'managed decline' narrative was prominent at the Aylesbury-

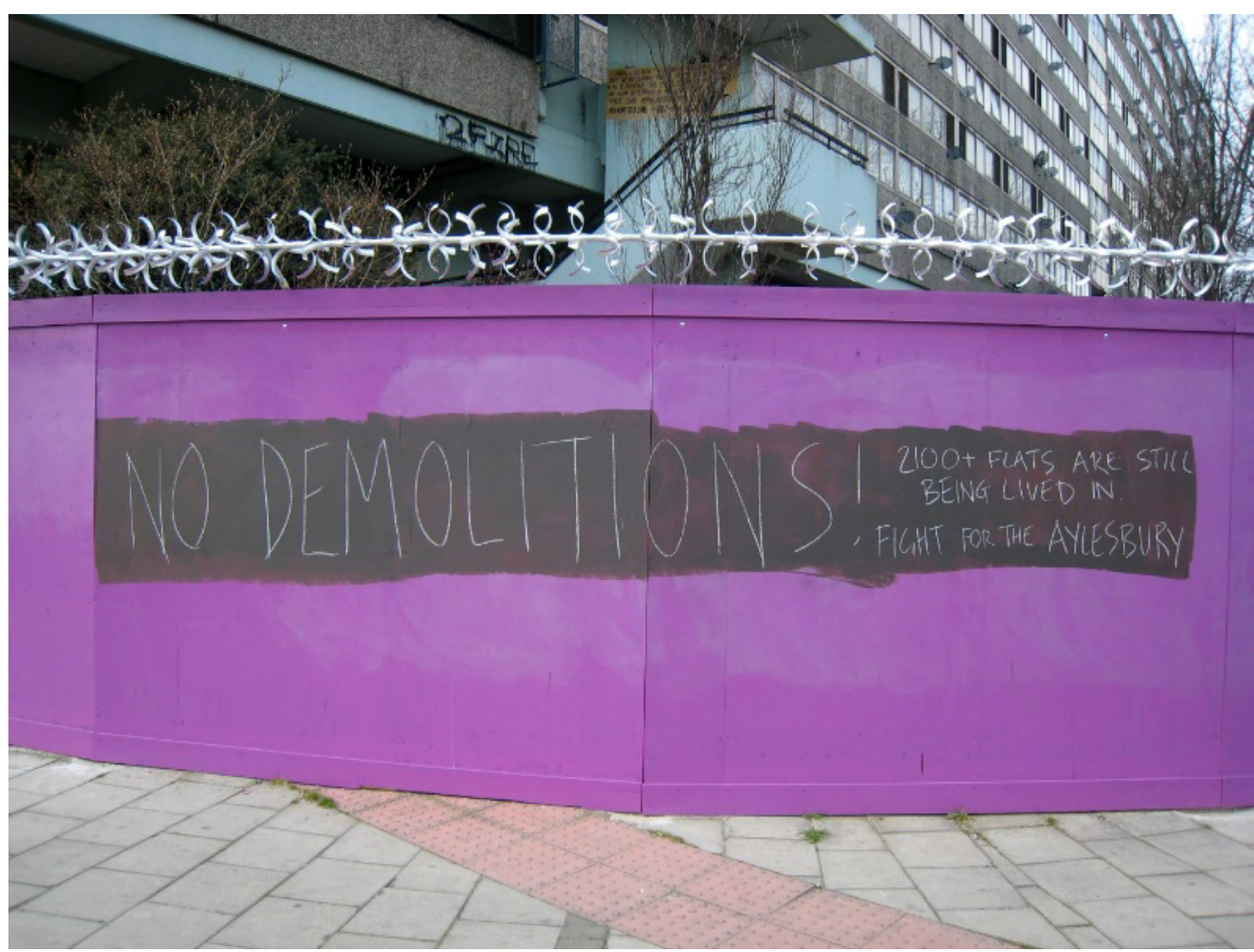

Figure 3. Aylesbury estate: Fortress and 'no demolitions!' 2015. Source: Paul Watt. 
that "the area's problems could be solved by allowing the neighbourhood to get worse and worse until it was no longer viable and had to be pulled down" (Davidson, McGuinness, Greenhalgh, Braidford, \& Robinson, 2013, p. 62). This narrative features in the above letter (Briden et al., 2005) - that the estate was being deliberately rundown via the actions and inactions of the council and its regeneration partners.

Residents felt they were being pressurised out of their homes due to the poor quality of maintenance and repairs; in other words, displacement as predicated on landlord neglect (Huq \& Harwood, 2019). As mentioned before, Mohammed had several housing problems, which prompted a desire to leave his flat: "I'm tired of the Aylesbury estate, I want to stay in the area but I want something new." Because of her flat's infestation, Hurmine was using the bidding system to transfer to another council property. At a 2014 meeting, a longterm female tenant complained of vermin infestation in one block while she described neighbours suffering from water dripping down the walls: "You come across people who say they want to get off the estate or out of the block as fast as they can." Shona (temporary tenant, white British) had only been living in her flat for a few months, but was desperate to be rehoused: "I hate it here, I cannot wait to leave, I've got so many holes in my floors, I've got mice, my 1-year old picked it up!" Dennis (council tenant, white British) had left the Aylesbury and was living in a council flat elsewhere in Southwark: "I'm glad I got out when I did, because I had a friend who stayed on and he had a terrible time there, the heating and water went, he said it was a nightmare." Others, however, were holding out and trying to resist the managed decline pressures: "They just want it to run down completely, frustrate us and then we move out, but they're not going to get us!" (Gesil).

One prominent physical aspect of managed decline is how the estate took on a forbidding fortress-like appearance due to supposedly enhanced 'security' (see Figure 3 with anti-demolition slogans): "We're fenced in, people think it's a prison" (female leaseholder, 2015 meeting; see also Southwark Council, 2016, leaseholder statements).

\section{Conclusion}

The Aylesbury estate has suffered from persistent and intensive territorial stigmatisation in Wacquant's termsas a 'notorious/sink estate/from hell'-which has occurred via extensive distorted national mass media coverage (Campkin, 2013; Romyn, 2019). However, despite such reputational 'taint of place,' there is little evidence of the blanket resident internalisation of territorial stigmatisation of the kind that Wacquant (2008) identified in Chicago and Parisian social housing estates. Instead, Aylesbury residents have largely disregarded, rejected, or actively resisted such stigmatisation (see Baxter, 2017; Lees, 2014; Rendell, 2017).
The Aylesbury estate was clearly a deprived area during the 1990s and early 2000s, one characterised by poverty, unemployment, low education, crime, antisocial behaviour, and fear of crime. However, it was by no means unusual in this regard by the standards of inner-city south-east London, and was furthermore one of the least deprived of the national NDC areas. More recently during the 2010s, the Aylesbury still has extensive poverty while unemployment is above the borough average and is especially a concern regarding BAME residents (Murray, 2012; Social Life, 2017). Nevertheless, other area-based deprivation indicators-educational attainment, crime, and fear of crime, for example-have substantially improved at the Aylesbury since 2000 , improvements which are, at least in part, due to the NDC and other regeneration-related community development efforts (ERS, 2010; Social Life, 2017). Aylesbury neighbourhood satisfaction levels increased since 2000 while place belonging is substantial and also well above the UK average, such that Wacquant's bleak 'dissolution of place' prognosis has scant applicability. On the other hand, housing (largely neglected within advanced marginality studies) has remained highly problematic for Aylesbury residents. The article emphasises their everyday difficulties and distress in trying to grapple with poor quality housing-non-functioning heating, damp, infestation, and inadequate repairs-despite their intrinsic valuation of their flats as spacious homes and for some with good views.

The research did not involve asking interviewees to directly compare territorial stigmatisation and housing experiences and this could be regarded as a potential weakness of the article; it is certainly something that future research should address. Nevertheless, the evidence strongly suggests that territorial stigmatisation is of relatively minor significance for Aylesbury residents in comparison to the frustration and sheer daily human misery they experienced due to the dilapidated, rundown state of their homes which itself reflects long-term under-investment in the estate and, as far as they were concerned, enhanced landlord neglect. Whereas territorial stigmatisation could be disregarded, residents could not disregard the dire state of their homes which also undoubtedly impacted upon their own and their family's health (Wilson et al., 2019). It is such poor housing which was forcing residents out of their homes-displacement-rather than territorial stigmatisation. Wacquant's comment $(2008$, p. 169)-that territorial stigmatisation is the "most protrusive feature" of residents' lived experiences in urban zones of advanced marginality-is not borne out in the Aylesbury case.

Two caveats are in order. First, I am not arguing that territorial stigmatisation has been of no significance at the Aylesbury estate. It undoubtedly has been significant, for example in helping to underpin the rationale for demolition and hence contributing to the resultant stateled gentrification in Southwark (Hubbard \& Lees, 2018; Lees, 2014). Second, the focus on social housing should 
not be interpreted to mean that this tenure monopolises poor quality accommodation. In fact, $38 \%$ of private renters live in poor housing in England compared to only $22 \%$ of social renters (Ministry of Housing, Communities and Local Government, 2018). Private tenants in London, particularly low-income tenants, often live in poor housing conditions while they also suffer from exorbitant rents and routine evictions which social tenants are cushioned from (Watt, 2018a, in press).

This article's key arguments are supported by the larger research project on London estate regeneration from which this case study is drawn (Watt, in press). First, that many London social housing estates are stigmatised, even if not to the same extreme degree as the Aylesbury. Second, that such stigmatisation is in the main discordant from residents' everyday experiences of place and neighbourhood. Third, that London estates suffer from under-investment and if anything enhanced neglect as they await demolition during the lengthy regeneration process in which living conditions steadily worsen for those in the remaining blocks of flats. As such, 'regeneration' is a misnomer since residents instead experience 'degeneration' as the quality of their homes and estate environment deteriorates. Fourth, that the academic prioritisation of territorial stigmatisation represents an analytical over-emphasis relative to estate residents' own concerns, notably their material living conditions regarding domestic and public space. Fifth, while London estates are not 'problem places,' neither are they places without problems and especially poor housing conditions which residents, quite rightly, want their landlords to address (Watt \& Allen, 2018). In conclusion, greater academic attention needs to be paid to highlighting social housing estate residents' own experiences and voices, especially regarding the material quality of their homes and neighbourhoods, while housing should be foregrounded, rather than neglected, in the analysis of the dynamics of urban advanced marginality.

\section{Acknowledgments}

The research was funded by Birkbeck, University of London. Thanks to the interviewees, Southwark housing campaigners and British Library staff for their assistance.

\section{Conflict of Interests}

The author declares no conflict of interests.

\section{References}

Attenburrow, J. J., Murphy, A. R., \& Simms, A. G. (1978). The problems of some large local authority estates: An exploratory study. London: Department of the Environment.

August, M. (2014). Challenging the rhetoric of stigmatization: The forgotten benefits of concentrated poverty in Toronto's Regent Park. Environment and Plan- ning $A, 46(6), 1317-1333$.

Barton, L. (2005, October 14). Death of an estate. The Guardian. Retrieved from https://www.theguardian. com/society/2005/oct/14/communities.g2

Baxter, R. (2017). The high-rise home: Verticality as practice in London. International Journal of Urban and Regional Research, 41(2), 334-352.

Beanland, C. (2014, March 14). Channel 4's Aylesbury estate ident gets a revamp: Starring the residents. The Guardian. Retrieved from https:// www.theguardian.com/tv-and-radio/2014/mar/14/ channel-4-aylesbury-estate-ident-revamped

Beatty, C., Grimsley, M., Lawless, P., Manning, J., \& Wilson, I. (2005). Fear of crime in NDC areas: How do perceptions relate to reality? Sheffield: CRESR, Sheffield Hallam University.

Bennington, J., Fordham, T., \& Robinson, D. (2004). Housing in London NDCs: Situations, challenges and opportunities (Research Report 59). Sheffield: CRESR, Sheffield Hallam University.

Blandy, S., Green, S., \& McCoulough, E. (2004). Boundary building in NDC areas (Research Report 39). Sheffield: CRESR, Sheffield Hallam University.

Boughton, J. (2018). Municipal dreams: The rise and fall of council housing. London: Verso.

Briden, V., Corbyn, P., Dennis, A., Esteve, F., Hibbert, N., \& Tarrawally, M. (2005, May 27). Letters: Expecting respect. South London Press.

Campkin, B. (2013). Regenerating London: Decline and regeneration in urban culture. London: I.B. Tauris.

Carter, H. (2008). Building the divided city: Race, class and social housing in Southwark, 1945-1995. The London Journal, 33(2), 155-185.

Castle, C., \& Atkinson, P. (2004). Aylesbury NDC community health profile. London: Southwark Primary Care Trust.

Centre for Regional Economic and Social Research. (2015). New Deal for Communities national evaluation phase 2: Technical report. London: Department of Communities and Local Government.

Christmann, K., Rogerson, M., \& Walters, D. (2003). Fear of crime and insecurity in New Deal for Communities partnerships (Research Report 14). Sheffield: CRESR, Sheffield Hallam University.

Coleman, A. (1990). Utopia on trial. London: Hilary Shipman.

Damer, S. (1974). Wine alley: The sociology of a dreadful enclosure. Sociological Review, 22(2), 221-248.

Davidson, G., McGuinness, D., Greenhalgh, P., Braidford, P., \& Robinson, F. (2013). 'It'll get worse before it gets better': Local experiences of living in a regeneration area. Journal of Urban Regeneration and Renewal, 7(1), 55-66.

Department of the Environment. (1981). An investigation of difficult to let housing. Volume 1: General findings. London: HMSO.

Eighteen, S. (2002, December 12). Without heat for fortnight. Southwark News. 
ERS. (2010). Aylesbury NDC: Physical environment theme evaluation. Bristol: ERS.

Flint, J., \& Powell, R. (Eds.). (2019). Class, ethnicity and state in the polarized metropolis. Basingstoke: Palgrave Macmillan.

Flynn, J. (2016). Complete control. City, 20(2), 278-286.

Gans, H. J. (1962). The urban villagers. New York, NY: The Free Press.

Garbin, D., \& Millington, G. (2012). Territorial stigma and the politics of resistance in a Parisian banlieue: La Courneuve and beyond. Urban Studies, 49(10), 2067-2083.

Hamnett, C. (2003). Unequal city: London in the global arena. London: Routledge.

Hancock, L., \& Mooney, G. (2013). 'Welfare ghettos' and the 'broken Society': Territorial stigmatization in the contemporary UK. Housing, Theory and Society, 30(1), 46-64.

Harrison, E., \& Lauder, L. (1997, June 12). Readers' letters: Tony Blair's visit. Southwark News.

Hastings, A. (2004). Stigma and social housing estates. Journal of Housing the Built Environment, 19(3), 233-254.

Helm, S. (2000, July 17). Lost souls in the city in the sky. New Statesman. Retrieved from https://www. newstatesman.com/node/151694

Hodkinson, S. (2019). Safe as houses. Manchester: Manchester University Press.

Hubbard, P., \& Lees, L. (2018). The right to community? City, 22(1), 8-25.

Huq, E., \& Harwood, S. (2019). Making homes unhomely: The politics of displacement in a gentrifying neighbourhood in Chicago. City \& Community, 18(2), 710-731.

Jacobs, K., \& Flanagan, K. (2013). Public housing and the politics of stigma. Australian Journal of Social Issues, 48(3), 319-337.

Jensen, S. Q., \& Christensen, A.-D. (2012). Territorial stigmatization and local belonging. City, 16(1/2), 74-92.

Johnston, C., \& Mooney, G. (2007). 'Problem' people, 'problem' spaces? New Labour and council estates. In R. Atkinson \& G. Helms (Eds.), Securing an urban renaissance: Crime, community and British urban policy (pp. 125-139). Bristol: Policy Press.

Johnston, K. (2019, July 31). Over f300k paid out to residents left in the cold. Southwark News. Retrieved from https://www.southwarknews.co.uk/ news/exclsuive-over-300k-paid-out-to-residents-leftin-the-cold

Kallin, H., \& Slater, T. (2014). Activating territorial stigma: Gentrifying marginality on Edinburgh's periphery. Environment \& Planning A, 46(6), 1351-1368.

Kelaher, M., Warr, D. J., Feldman, P., \& Tacticos, T. (2010). Living in 'Birdsville': Exploring the impact of neighbourhood stigma on health. Health \& Place, 16(2), 381-388.

Lees, L. (2014). The urban injustices of New Labour's
'New Urban Renewal': The case of the Aylesbury Estate in London. Antipode, 46(4), 921-947.

Luba, J. (2012). Investing in council housing: Options for the future. A report by the independent commission on the future of council housing in Southwark. London: Southwark Council.

Ministry of Housing, Communities and Local Government. (2018). English housing survey: Stock condition, 2016. London: Ministry of Housing, Communities and Local Government.

Morgan, B. (2014, January 31). A new identity: Name change to help estate shake off reputation in $£ 1.5 \mathrm{bn}$ rebuild. South London Press.

Morris, A. (2013). Public housing in Australia: A case of advanced urban marginality? The Economic and Labour Relations Review, 24(1), 80-96.

Mullany, C. (2002a, January 3). Aylesbury tenants reject transfer. Southwark News.

Mullany, C. (2002b, April 18). Aylesbury transfer proposal was 'loaded choice' says Harman. Southwark News.

Murray, K. (2012). Understanding the impact of the economic down turn on BAME communities: A case study of the Aylesbury estate in the London Borough of Southwark. London: Black Training and Enterprise Group.

News Desk. (2017, February 9). Hundreds of families left without heating and hot water for months demand refunds. Southwark News. Retrieved from https://www.southwarknews.co.uk/news/hundredsfamilies-left-without-heating-hot-water-monthsdemand-refunds

No-go Britain: Where, what, why. (1994, April 17). The Independent. Retrieved from https://www. independent.co.uk/news/uk/no-go-britain-wherewhat-why-1370749.html

Opinion Research Services. (2009). Southwark housing requirements study 2008: Aylesbury estate. Swansea: Opinion Research Services.

Porter, T. (2018, March 2). No hot water for weeks as UK freezes. South London Press.

Powell, R., \& Robinson, D. (2019). Housing, ethnicity and advanced marginality in England. In J. Flint \& R. Powell (Eds.), Class, ethnicity and state in the polarized metropolis (pp. 187-212). Basingstoke: Palgrave Macmillan.

Quinn, K. (2002, September 5). Tenants set to hire security guards in fight against crack house plague. Southwark News.

Rendell, J. (2017). 'Arry's Bar: Condensing and displacing on the Aylesbury estate. The Journal of Architecture, 22(3), 532-554.

Robson, G. (2000). 'No one likes us, we don't care': The myth and reality of Millwall fandom. Oxford: Berg.

Romyn, M. (2019). 'London badlands': The inner city represented, regenerated. The London Journal, 44(2), 133-150.

Slater, T. (2018). The invention of the 'sink estate': Consequential categorisation and the UK housing crisis. 
Sociological Review Monographs, 66(4), 877-897.

Social Life. (2017). Living on the Aylesbury estate. London: Social Life.

Southwark Council. (2005). The Aylesbury estate: Revised strategy, 27 September. London: Southwark Council.

Southwark Council. (2016). Overview \& scrutiny committee: 10 October 2016. London: Southwark Council.

Southwark Council. (2018). Minutes of the open section of the Cabinet, 24 July. London: Southwark Council.

Southwark Council. (2019). Freedom of information request (Ref. 1499185). London: Southwark Council.

Wacquant, L. (2008). Urban outcasts: A comparative sociology of advanced marginality. Cambridge: Polity Press.

Wacquant, L. (2019). Dispossession and dishonour in the polarized metropolis: Reactions and recommendations. In J. Flint \& R. Powell (Eds.), Class, ethnicity and state in the polarized metropolis (pp. 309-323). Basingstoke: Palgrave Macmillan.

Watt, P. (2008). 'Underclass' and ordinary people' discourses: Representing/re-presenting council tenants in a housing campaign. Critical Discourse Studies, 5(3), 345-357.

Watt, P. (2009). Social housing and regeneration in London. In R. Imrie, L. Lees, \& M. Raco (Eds.), Regenerating London (pp. 212-233). London: Routledge.

Watt, P. (2013). 'It's not for us': Regeneration, the 2012
Olympics and the gentrification of East London. City, 17(1), 99-118.

Watt, P. (2018a). 'This pain of moving, moving, moving': Evictions, displacement and logics of expulsion in London. L'Année Sociologique, 68(1), 67-100.

Watt, P. (2018b). 'Social housing not social cleansing': Contemporary housing struggles in London. In $\mathrm{N}$. Gray (Ed.), Rent and its discontents: A century of housing struggle (pp. 117-135). London: Rowman \& Littlefield.

Watt, P. (in press). Estate regeneration and its discontents: Public housing, place and inequality in London. Bristol: Policy Press.

Watt, P., \& Allen, D. (2018). Northwold estate, Hackney: A report on residents' attitudes to the estate and its potential redevelopment. London: Birkbeck, University of London.

Watt, P., \& Jacobs, K. (2000). Discourses of social exclusion: An analysis of Bringing Britain Together. A national strategy for neighbourhood renewal. Housing, Theory and Society, 17(1), 14-26.

Watt, P., \& Smets, P. (2017). Social housing and urban renewal: A cross-national perspective. Bingley: Emerald.

Wilson, W., O'Donnell, M., Bellis, A., \& Barton, C. (2019). The cost of unhealthy housing to the National Health Service. London: House of Commons Library.

\section{About the Author}

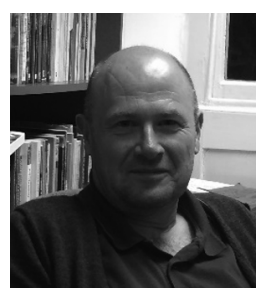

Paul Watt is Professor of Urban Studies at the Department of Geography, Birkbeck, University of London. He has published widely on social housing, urban regeneration, homelessness, housing activism, gentrification, suburbanisation, and the London 2012 Olympic Games. He is a member of the City collective editorial board, and is currently Co-Chair of the Haringey Fairness Commission. 